\title{
Modeling the Effective Factors on Bank Loans Default Rate Using Delphi, SEM and Tobit Techniques (Evidence from Iran)
}

\author{
Hamid Safaynikou ${ }^{1}$, Mohammad Taher Ahmadi Shadmehri ${ }^{2}$, Ahmad Sabahi ${ }^{2} \&$ Mohammad Javad Razmi $^{2}$ \\ ${ }^{1}$ Ph.D. student of economic, Ferdowsi University of Mashhad, International Campus, Mashhad, Iran \\ ${ }^{2}$ Associated Professors of Economics, Ferdowsi University of Mashhad, Iran \\ Correspondence: Mohammad Taher Ahmadi Shadmehri, Department of Economics, Ferdowsi University of \\ Mashhad, Mashhad, Iran. E-mail: shadmhri@um.ac.ir
}

Received: Nov. 3, 2016

Accepted: November 21, 2016

Online Published: January 24, 2017

doi:10.5539/mas.v11n4p13

URL: https://doi.org/10.5539/mas.v11n4p13

\begin{abstract}
Banks entering a developing market face a lot of uncertainty about the risks involved in lending. This paper models the effective factors on default rate (DR) loans to small and medium size enterprises (SMEs) in Iran based on the case study of branches of Melli Bank in Khorasan Razavi province. For this purpose a set of data about loans made to 300 SMEs between years 2004 to 2015 and Delphi, SEM and Tobit models were applied. Results of Delphi technique indicated that 48 factors affect the DR. The structural equation model (SEM) estimations showed that between 10 latent variables which describe the DR, the "loans properties" latent variable have the most effect. Also, findings of Tobit econometric model stated that between 48 variables which affect the DR, "loan volume" variable has the most effect. These and other factors emphasize the need for SMEs credit scoring in developing countries.
\end{abstract}

Keywords: SME, loan default rate (DR), Delphi, SEM, Tobit

\section{Introduction}

Small and medium sized enterprises (SMEs) have played a critical role in industrial and economic development globally. According to the Organization for Economic Cooperation and Development report, SMEs are convincingly the backbone of the economy of countless countries across the world. Also, Available empirical evidence illustrates that SMEs are relatively more important in developing and less developed countries than in developed countries (Apiri, 2013). Recently, SMEs financing in Iran is receiving increased attention given the importance of SMEs in the economy, especially in employment generation. But many firms in Iran complain that access to finance represents a major impediment to doing business. SMEs find it particularly difficult to get loans. This means that, due to the lack of financial intermediation, their potential contributions to growth and employment are wasted. Thus, these markets can be expected to keep growing in the future provided the firms are credit-worthy. On the other hand, fueled by increasing income and positive growth expectations, lending has increased significantly (Coricelli et al., 2006). From a macroeconomic perspective, however, concerns about a "lending boom" have been raised recently (Duenwald et al., 2005). An expansion of credit may increase the probability of a banking crisis if, during the credit boom period, the quality of the evaluation of credit proposals suffers (Khieu et al, 2011). However, we know little about the default rates of bank loans. Although there is evidence on the default and mortality rates of bonds, it is hard to transfer the results in this field to corporate loans (Wongnaa and Awonyu-Vitor, 2013). The limit studies on default of bank loans are such on syndicated loans to corporate debtors (Altman and Suggitt, 2000, Yong Seo, 2011 and Sylvester, 2013) and pattern of loans to individual firms in a fast growing emerging economy (Fidrmuc et al., 2006 and Saunders \& Allen, 2002). What is still missing is evidence of the default model of loans to SMEs in a developing economy. While there is some literature on access to finance for SMEs in Iran, there is no economic literature on the performance of SME loans, including their default rates. In this research we analyze this issue in branches of Melli bank in Khorasen-e- Razavi province of Iran between 2004 and 2015. The paper is organized as follows. Section 2 provides a survey of the literature on loan defaults. Section 3 describes our data set, and Section 4 presents the results of modeling effective factors on bank loans default rate using Delphi, SEM and Tobit models in Iran. Section 5 concludes. 


\section{Literature Review}

There is no consensus on a single definition of SMEs; however, there is a level of agreement among researchers on the crucial role of SMEs in economic development (Adejumo and Olaoye, 2012). Sutcliffe (1971) noted that there are a greater number of small firms than medium-sized firms in developing and less developed countries compared to industrialized countries. Despite the difference in terms of operation and activities across different countries, a significant portion of the growth of large-scale enterprises (LSEs) are brought about by the activities of SMEs (Anderson, 1982), as they can be located in rural and a sub-urban areas (Kilby, 1971) and they have a tendency to employ more labor intensive methods than the LSEs and thereby create more employment opportunities (Sutcliffe, 1971). Extensive research work has been carried out on the problems facing SMEs and reasons for their failures; the most formidable problem inhibiting SMEs is the lack of finance and that is why development literature has paid attention to issues confronting SMEs in accessing finance (Mora, 2012). On the other hand, credit risk or default is a common feature in the credit market in developing and developed countries, as history has shown the loan default to be a major factor accounting for the global financial crisis (Calomiris and Beim, 2001). According to Fry (1995), the chance of default of SME loans from the informal market is quite low. This is a result of the ability of the informal sector to understand the SME sector, particularly the informal sector in Iran where SMEs are a major player. On the contrary, the default rate of SMEs in the formal financial market is quite high in all economies, particularly emerging and developing countries such as Iran. According to the importance of SMEs and their loans default, many researchers have been studied the factors which affect the loans default in this sector. For example, Asarnow and Edwards (1995) examined 831 defaulted loans at Citibank over the period 1970-1993. They reported an average cumulative recovery rate of $65 \%$, based on the present value of future cash flows received after the default date. A significant result of that study was that the distribution of recovery rates was bi-modal, with a concentration of recovery rates on either the low or the high end of the distribution. La Porta et al (2003) analyzed loan default and losses-given-default in Mexico in the context of 'related lending', that is, lending to shareholders or directors of the bank. They reported an average recovery rate of $46 \%$ for 'unrelated' loans, and $27 \%$ for 'related' loans over the period 1995-1999. Evidence of skewness toward the high end of the distribution was also reported. Fidrmuc et al. (2006) used a unique unbalanced panel of nearly 700 short-term loans made to SMEs in Slovakia between January 2000 and June 2005. They concluded that liquidity and profitability factors are important determinants of SMEs defaults, while debt factors are less robust. Mora (2012) examined whether recovery rates are affected by systematic conditions in the economy-whether the overall performance of the economy, the conditions in the bond market for distressed debt, or industry illiquidity. The results suggest that the recovery rate depends on systematic and industry wide factors. Also, it is more difficult, however, to precisely determine which factor is primarily responsible for driving recovery risk. Apiri (2013) examined the default rate and performance of Microfinance bank (MFBs) loans to SMEs in Nigeria. Using responses from 150 employees of MFB he revealed that the causes of default rate and performance of SMEs reflect the risk and vulnerability of the SME sector in Nigeria. He further showed that MFBs apply stringent credit criteria in granting loans to SME borrowers, coupled with the existing high cost of funds. Shah (2014) used survey data gathered from 96 SME loan recipients, now in default, to explore the factors contributing to high SME default rates. He concluded that major factors contributing to the high default rate on SME loans in Bangladesh include general strikes and blockades, high competition, lack of business capital, slow seasonal sales, and issues such as fund diversion. Oludayo (2015) studied the determinants of loan default and repayment rates with the case Study of bank of agriculture (BOA) and first bank of Nigeria (BON). He found that BOA had a better repayment rate than FBN. Major constraints to loan administration in the study area were non-repayment of loan by beneficiaries, delay in repayment of loans and diversion of agricultural loans to non-agricultural sector among others. It was concluded that high default rate limited agricultural loan administration in the study area.

According to missing evidence of the default model of loans to SMEs and lack of economic literature on the performance of SME loans, including their default rates in a developing economy, in this paper we model the effective factors on bank loans default rate using Delphi, SEM and Tobit techniques in Iran.

\section{Method}

\subsection{Delphi Technique}

The Delphi method's flexibility is evident in how it has been used. It is a method for structuring a group communication process to facilitate group problem solving and to structure models. The method can also be used as a judgment, decision-aiding or forecasting tool, and can be applied to program planning and administration. The Delphi method can be used when there is incomplete knowledge about a problem or phenomena (Rowe and Wright, 1999). The method can be applied to problems that do not lend themselves to precise analytical 
techniques but rather could benefit from the subjective judgments of individuals on a collective basis and to focus their collective human intelligence on the problem at hand. Also, the Delphi is used to investigate what does not yet exist. The Delphi method is a mature and a very adaptable research method used in many research arenas by researchers across the globe. To better understand its diversity in application, one needs to consider the origins of the Delphi method (Skulmoski and Hartman 2002). Figure 1 illustrates the three round Delphi process:

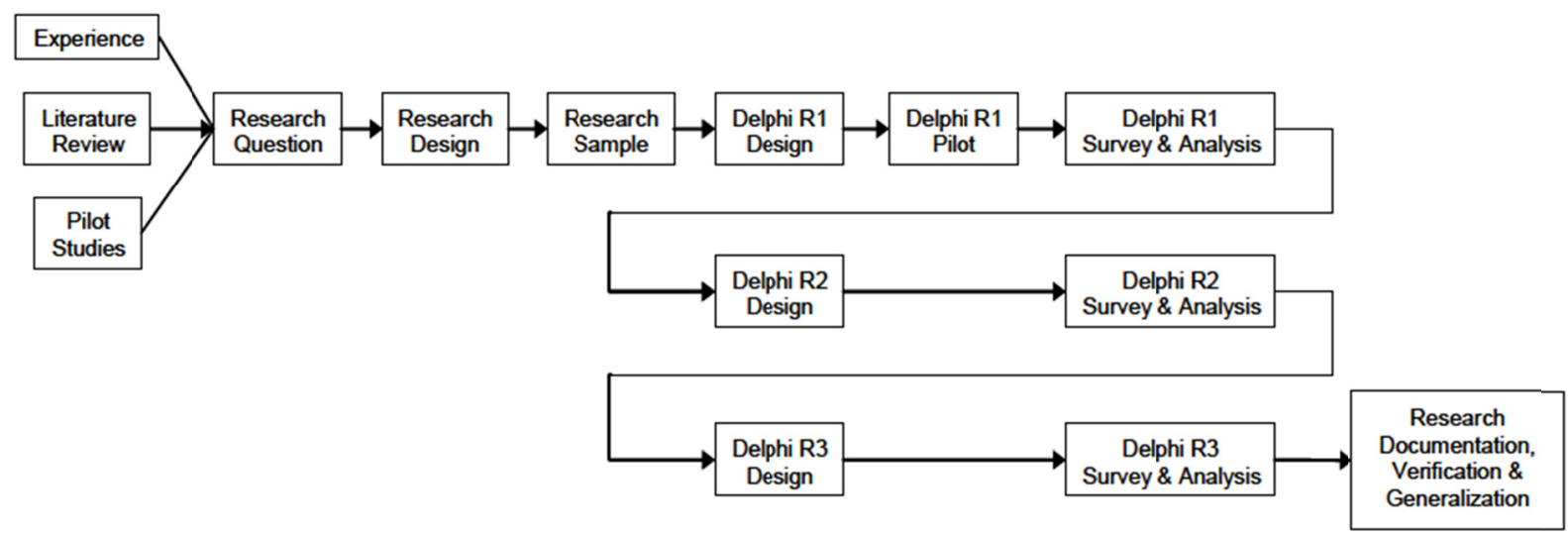

Figure 1. Three round Delphi process

In this research the Delphi technique will apply for assessing the factors which affect the loan default rate and its questionnaires will distribute between 10 experts of credit union of Melli bank in Korasan Razavi province of Iran.

\subsection{SEM Model}

Analyzing research data and interpreting results can be complex and confusing. Traditional statistical approaches to data analysis specify default models, assume measurement occurs without error, and are somewhat inflexible. However, structural equation modeling requires specification of a model based on theory and research, is a multivariate technique incorporating measured variables and latent constructs, and explicitly specifies measurement error. A model (diagram) allows for specification of relationships between variables. Structural equation modeling (SEM) is a methodology for representing, estimating, and testing a network of relationships between variables (measured variables and latent constructs) (MacCallum \& Austin, 2000). A suggested approach to SEM analysis proceeds through the following process:

- Review the relevant theory and research literature to support model specification

- $\quad$ Specify a model (e.g., diagram, equations)

- Determine model identification (e.g., if unique values can be found for parameter estimation; the number of degrees of freedom, df, for model testing is positive)

- Select measures for the variables represented in the model

- Collect data

- Conduct preliminary descriptive statistical analysis Estimate parameters in the model

- Assess model fit

- Specify the model if meaningful

- Interpret and present results.

In this research after assessing the factors which affect the loan default rate with Delphi technique, the SEM model will apply for studying the effect of latent variables on loans default rate.

\subsection{Tobit Model}

As Wooldridge (2002) makes clear, censored regression applications fall into two categories:

1. Censored Regression Applications: In this application, we have true censoring as outlined above. There is a variable with quantitative meaning, $y^{*}$ and we are interested in the population regression $E\left(y^{*}\right)$. If $y^{*}$ were observed for everyone in the population, we could use OLS etc. However, a data problem arises in that $y^{*}$ is censored from above and/or below i.e. it is not observed for some part of the population. 
2. Corner Solution Models: In the second application, though, it seems misleading to use the terminology of censoring. In this application, $y$ is an observable choice or outcome describing some agent with the following characteristics: $y$ takes on the value 0 with positive probability but is a continuous random variable over strictly positive values. In effect, we have an agent who is solving a maximization problem. For some of these individuals, the optimal choice will be the corner solution, $y=0$. It seems better to refer to these types of models as corner solution models rather than censored regression models. Note that in the corner solution applications, the issue is NOT data observability: we are interested in features of the distribution of $y$ such as $E(y)$ and $P(y=0)$. As Wooldridge points out, it is problematic to use OLS in this setting.

Both types of application - the censored regression application and the corner solution application - lead to the standard censored Tobit model. The structural equation in the Tobit model is:

$$
y_{i}^{*}=X_{i} \beta+\varepsilon_{i}
$$

Where $\varepsilon_{i} \approx N\left(0, \sigma^{2}\right) \cdot y^{*}$ is a latent variable that is observed for values greater than $\pi$ and censored otherwise. The observed $y$ is defined by the following measurement equation:

$$
y_{i}=\left\{\begin{array}{lll}
y^{*} & \text { if } & y^{*}>\pi \\
\pi_{y} & \text { if } & y^{*} \leq \pi
\end{array}\right.
$$

In the typical tobit model, we assume that $\pi=0$ i.e. the data are censored at 0 . Thus, we have:

$$
y_{i}=\left\{\begin{array}{lll}
y^{*} & \text { if } & y^{*}>0 \\
0 & \text { if } & y^{*} \leq 0
\end{array}\right.
$$

In this research after assessing the factors which affect the loan default rate with Delphi technique, and studying the effect of latent variables on loans default rate with SEM model, the Tobit econometric model will apply for investigating the elasticity of loan default rate to all assessed factors.

\section{Data Collection}

Statistical society of this research concludes of whole SMEs which have received loans from branches of Melli bank in Korasan Razavi province of Iran during 2004-2015. In order to determine the sample volume a pre test was carried out which trough it at fist 30 companies randomly selected and the properties of their allocated loans were gathered. Then the variance of default rate for these companies was calculated and using Cochran's formula for infinite society (considering 0.95 significant levels) the volume of required sample determined equal to 300 companies. Also, the primary data analysis indicated that among 300 companies, whole or part of loans allocated to 172 companies were defaulted and loans allocated to 128 companies were completely recovered. Further, the average rate of loans default is equal to $9.87 \%$. Finally, for assessing the factors which affect the loan default rate, the questionnaires of Delphi technique distributed between 10 experts of credit union of Melli bank in Korasan Razavi province of Iran.

\section{Results and Discussion}

In order to model the effective factors on bank loans default rate using Delphi, SEM and Tobit techniques at first the whole effective factors on bank loans default were listed by related literature reviewing. We found that totally 60 variables have been applied in previous studies. Using three round Delphi process we assess the 48 final variables which affect the bank loans default. Then using SEM model we evaluate the effect of 10 latent variables on bank loans default rate. Table 1 indicates the final effective factors and effect of 10 latent variables on bank loans default rate of considered SMEs and Table 2 shows the results of Tobit model.

Table 1. Final effective factors and effect of latent variables on bank loans default rate

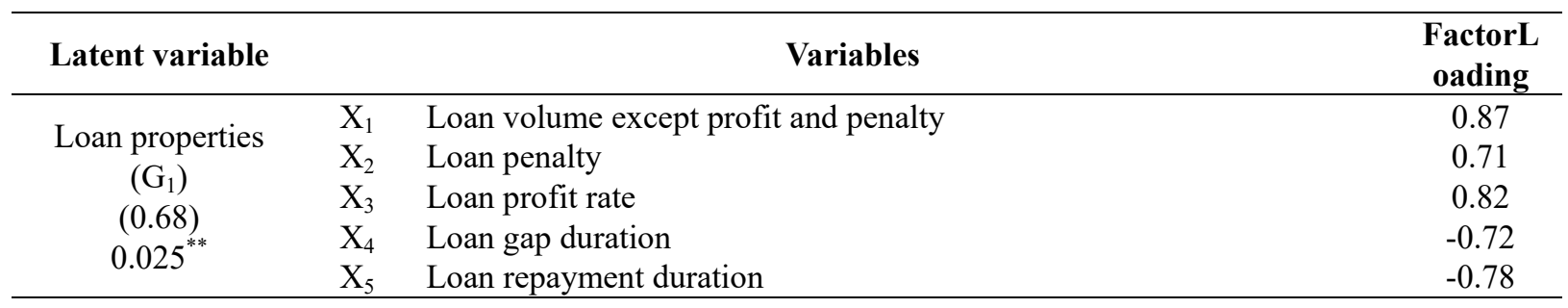




\begin{tabular}{|c|c|c|c|}
\hline \multirow{7}{*}{$\begin{array}{c}\text { Company } \\
\text { properties }\left(\mathrm{G}_{2}\right) \\
(0.51) \\
0.076^{*}\end{array}$} & $\mathrm{X}_{6}$ & Company's background & -0.66 \\
\hline & $\mathrm{X}_{7}$ & Company's corporation with Bank Melli Iran & -0.58 \\
\hline & $\mathrm{X}_{8}$ & Company's manager age & -0.46 \\
\hline & $\mathrm{X}_{9}$ & Company's manager background & -0.49 \\
\hline & $\mathrm{X}_{10}$ & $\begin{array}{l}\text { Professional education of manager coordination with company's } \\
\text { activity }\end{array}$ & -0.38 \\
\hline & $\mathrm{X}_{11}$ & Company's manager and boards delayed debt before loan allocation & 0.55 \\
\hline & $\mathrm{X}_{12}$ & Company's co-grouping & 0.48 \\
\hline \multirow{6}{*}{$\begin{array}{c}\text { Company's } \\
\text { banking account } \\
\text { properties }\left(\mathrm{G}_{3}\right) \\
(0.60) \\
0.049^{* *}\end{array}$} & $\mathrm{X}_{13}$ & $\begin{array}{l}\text { Company's current account creditor flow at the loan allocation last } \\
\text { year }\end{array}$ & -0.64 \\
\hline & $\mathrm{X}_{14}$ & Company's current account creditor flow at the loan allocation year & -0.58 \\
\hline & $\mathrm{X}_{15}$ & Company's total amount of direct debt to banking system & 0.70 \\
\hline & $\mathrm{X}_{16}$ & Company's total amount of indirect debt to banking system & 0.61 \\
\hline & $\mathrm{X}_{17}$ & Company's dishonoured cheque & 0.63 \\
\hline & $\mathrm{X}_{18}$ & Cash flow/total debt proportion & -0.65 \\
\hline \multirow{7}{*}{$\begin{array}{c}\text { Company's } \\
\text { financial } \\
\text { proportions }\left(\mathrm{G}_{4}\right) \\
(0.57) \\
0.058^{* *}\end{array}$} & $\mathrm{X}_{19}$ & Assets flow proportion & -0.56 \\
\hline & $\mathrm{X}_{20}$ & Free cash flow proportion & -0.58 \\
\hline & $\mathrm{X}_{21}$ & Total debt proportion & 0.44 \\
\hline & $\mathrm{X}_{22}$ & Cash proportion & -0.51 \\
\hline & $\mathrm{X}_{23}$ & Cash current proportion & -0.59 \\
\hline & $\mathrm{X}_{24}$ & Debt proportion & 0.57 \\
\hline & $\mathrm{X}_{25}$ & Installment sale to industry, mine and agriculture sectors & 0.39 \\
\hline \multirow{5}{*}{$\begin{array}{c}\text { Loan type }\left(\mathrm{G}_{5}\right) \\
(0.35) \\
0.124^{\mathrm{NS}}\end{array}$} & $\mathrm{X}_{26}$ & Installment sale to industry, mine, services and agriculture sectors & 0.38 \\
\hline & $\mathrm{X}_{27}$ & Equity participation (real estate sector) & 0.40 \\
\hline & $\mathrm{X}_{28}$ & Equity participation (industry, mine and agriculture sectors) & 0.37 \\
\hline & $\mathrm{X}_{29}$ & Equity participation (trade and services sectors) & 0.35 \\
\hline & $\mathrm{X}_{30}$ & Mudaraba (domestic trade and export sectors) & 0.39 \\
\hline \multirow{4}{*}{$\begin{array}{c}\text { Company's type } \\
\left(\mathrm{G}_{6}\right) \\
(0.34) \\
0.126^{\mathrm{NS}}\end{array}$} & $\mathrm{X}_{31}$ & Company’s type: private joint stock & 0.36 \\
\hline & $\mathrm{X}_{32}$ & Company's type: public joint stock & 0.34 \\
\hline & $\mathrm{X}_{33}$ & Company's type: corporative & 0.33 \\
\hline & $\mathrm{X}_{34}$ & Company's type: other & 0.32 \\
\hline \multirow{5}{*}{$\begin{array}{c}\text { Company’s } \\
\text { activity }\left(\mathrm{G}_{7}\right) \\
(0.38) \\
0.115^{\mathrm{NS}}\end{array}$} & $\mathrm{X}_{35}$ & Company's activity: industry and mine sector & 0.39 \\
\hline & $\mathrm{X}_{36}$ & Company's activity: agriculture sector & 0.39 \\
\hline & $\mathrm{X}_{37}$ & Company's activity: real estate sector & 0.40 \\
\hline & $\mathrm{X}_{38}$ & Company’s activity: services sector & 0.41 \\
\hline & $\mathrm{X}_{39}$ & Company's activity: trade sector & 0.43 \\
\hline \multirow{4}{*}{$\begin{array}{c}\text { Banking } \\
\text { guaranty's type } \\
\left(\mathrm{G}_{8}\right) \\
(0.64) \\
0.037^{* *}\end{array}$} & $\mathrm{X}_{40}$ & Bank guarantee: immovable property & -0.59 \\
\hline & $\mathrm{X}_{41}$ & Bank guarantee: bank deposit or bonds & -0.64 \\
\hline & $\mathrm{X}_{42}$ & Bank guarantee: promissory note or cheque & -0.71 \\
\hline & $\mathrm{X}_{43}$ & Bank guarantee: other & -0.68 \\
\hline \multirow{3}{*}{$\begin{array}{c}\text { Economic } \\
\text { situations }\left(\mathrm{G}_{9}\right) \\
(0.59) \\
0.052^{*}\end{array}$} & $\mathrm{X}_{44}$ & Exchange rate & 0.49 \\
\hline & $\mathrm{X}_{45}$ & Inflation rate & 0.66 \\
\hline & $\mathrm{X}_{46}$ & Economic sanction & 0.72 \\
\hline \multirow{2}{*}{$\begin{array}{c}\text { Bank monitoring } \\
\left(\mathrm{G}_{10}\right) \\
(0.61)^{* *} \\
-0.046^{* *}\end{array}$} & $\mathrm{X}_{47}$ & Bank control on loans & -0.70 \\
\hline & $\mathrm{X}_{48}$ & Company's financial reports auditing by official auditors association & -0.58 \\
\hline not sionifica & & at $90 \%$ interval level- * & \\
\hline
\end{tabular}


Table 2. Estimationof default rate function using Tobit model

\begin{tabular}{|c|c|c|c|c|c|c|}
\hline Variables & $\begin{array}{c}\text { Normalized } \\
\text { coefficient }\end{array}$ & $\mathrm{t}$ statistic & P-value & $\begin{array}{l}\text { Approval } \\
\text { elasticity }\end{array}$ & $\begin{array}{l}\text { Expected } \\
\text { elasticity }\end{array}$ & Total elasticity \\
\hline $\mathrm{X}_{1}$ & 0.371 & 2.61 & $0.009^{* * *}$ & 0.077 & 0.057 & 0.134 \\
\hline $\mathrm{X}_{2}$ & 0.247 & 2.13 & $0.033^{* *}$ & 0.034 & 0.025 & 0.060 \\
\hline $\mathrm{X}_{3}$ & 0.330 & 2.46 & $0.014^{* *}$ & 0.061 & 0.045 & 0.106 \\
\hline $\mathrm{X}_{4}$ & -0.254 & -2.16 & $0.031^{* *}$ & -0.036 & -0.027 & -0.063 \\
\hline $\mathrm{X}_{5}$ & -0.298 & -2.34 & $0.019^{* *}$ & -0.050 & -0.037 & -0.087 \\
\hline $\mathrm{X}_{6}$ & -0.213 & -1.98 & $0.048^{* *}$ & -0.026 & -0.019 & -0.045 \\
\hline $\mathrm{X}_{7}$ & -0.165 & -1.74 & $0.080^{*}$ & -0.015 & -0.011 & -0.027 \\
\hline $\mathrm{X}_{8}$ & -0.104 & -1.38 & $0.168^{\mathrm{NS}}$ & -0.006 & -0.005 & -0.011 \\
\hline $\mathrm{X}_{9}$ & -0.118 & -1.47 & $0.142^{\mathrm{NS}}$ & -0.007 & -0.006 & -0.013 \\
\hline $\mathrm{X}_{10}$ & -0.071 & -1.14 & $0.254^{\mathrm{NS}}$ & -0.003 & -0.002 & -0.005 \\
\hline $\mathrm{X}_{11}$ & 0.148 & 1.65 & $0.099^{*}$ & 0.012 & 0.009 & 0.020 \\
\hline $\mathrm{X}_{12}$ & 0.113 & 1.44 & $0.150^{\mathrm{NS}}$ & 0.007 & 0.005 & 0.012 \\
\hline $\mathrm{X}_{13}$ & -0.201 & -1.92 & $0.055^{*}$ & -0.022 & -0.016 & -0.038 \\
\hline $\mathrm{X}_{14}$ & -0.165 & -1.74 & $0.080^{*}$ & -0.015 & -0.011 & -0.026 \\
\hline $\mathrm{X}_{15}$ & 0.240 & 2.10 & $0.036^{* *}$ & 0.031 & 0.023 & 0.054 \\
\hline $\mathrm{X}_{16}$ & 0.182 & 1.83 & $0.067^{*}$ & 0.018 & 0.013 & 0.031 \\
\hline $\mathrm{X}_{17}$ & 0.195 & 1.89 & $0.059^{*}$ & 0.020 & 0.015 & 0.036 \\
\hline $\mathrm{X}_{18}$ & -0.207 & -1.95 & $0.051^{*}$ & -0.024 & -0.018 & -0.041 \\
\hline $\mathrm{X}_{19}$ & -0.154 & -1.68 & $0.093^{*}$ & -0.013 & -0.010 & -0.023 \\
\hline$X_{20}$ & -0.165 & -1.74 & $0.082^{*}$ & -0.015 & -0.011 & -0.026 \\
\hline $\mathrm{X}_{21}$ & 0.095 & 1.32 & $0.187^{\mathrm{NS}}$ & 0.005 & 0.004 & 0.009 \\
\hline $\mathrm{X}_{22}$ & -0.127 & -1.53 & $0.126^{\mathrm{NS}}$ & -0.009 & -0.007 & -0.016 \\
\hline$X_{23}$ & -0.171 & -1.77 & $0.077^{*}$ & -0.016 & -0.012 & -0.028 \\
\hline $\mathrm{X}_{24}$ & 0.159 & 1.71 & $0.087^{*}$ & 0.014 & 0.010 & 0.024 \\
\hline$X_{25}$ & 0.075 & 1.17 & $0.242^{\mathrm{NS}}$ & 0.003 & 0.002 & 0.005 \\
\hline$X_{26}$ & 0.071 & 1.14 & $0.254^{\mathrm{NS}}$ & 0.003 & 0.002 & 0.005 \\
\hline $\mathrm{X}_{27}$ & 0.078 & 1.20 & $0.230^{\mathrm{NS}}$ & 0.003 & 0.003 & 0.006 \\
\hline $\mathrm{X}_{28}$ & 0.067 & 1.11 & $0.267^{\mathrm{NS}}$ & 0.002 & 0.002 & 0.004 \\
\hline $\mathrm{X}_{29}$ & 0.060 & 1.05 & $0.294^{\mathrm{NS}}$ & 0.002 & 0.001 & 0.003 \\
\hline $\mathrm{X}_{30}$ & 0.075 & 1.17 & $0.242^{\mathrm{NS}}$ & 0.003 & 0.002 & 0.005 \\
\hline $\mathrm{X}_{31}$ & 0.064 & 1.08 & $0.280^{\mathrm{NS}}$ & 0.002 & 0.002 & 0.004 \\
\hline $\mathrm{X}_{32}$ & 0.057 & 1.02 & $0.308^{\mathrm{NS}}$ & 0.002 & 0.001 & 0.003 \\
\hline$X_{33}$ & 0.053 & 0.99 & $0.322^{\mathrm{NS}}$ & 0.002 & 0.001 & 0.003 \\
\hline $\mathrm{X}_{34}$ & 0.050 & 0.96 & $0.337^{\mathrm{NS}}$ & 0.001 & 0.001 & 0.003 \\
\hline $\mathrm{X}_{35}$ & 0.075 & 1.17 & $0.242^{\mathrm{NS}}$ & 0.003 & 0.002 & 0.006 \\
\hline $\mathrm{X}_{36}$ & 0.075 & 1.17 & $0.242^{\mathrm{NS}}$ & 0.003 & 0.002 & 0.005 \\
\hline$X_{37}$ & 0.078 & 1.20 & $0.230^{\mathrm{NS}}$ & 0.003 & 0.003 & 0.006 \\
\hline $\mathrm{X}_{38}$ & 0.082 & 1.23 & $0.215^{\mathrm{NS}}$ & 0.004 & 0.003 & 0.007 \\
\hline $\mathrm{X}_{39}$ & 0.091 & 1.29 & $0.197^{\mathrm{NS}}$ & 0.005 & 0.003 & 0.008 \\
\hline $\mathrm{X}_{40}$ & -0.171 & -1.77 & $0.077^{*}$ & -0.015 & -0.011 & -0.027 \\
\hline $\mathrm{X}_{41}$ & -0.201 & -1.92 & $0.055^{*}$ & -0.021 & -0.016 & -0.037 \\
\hline $\mathrm{X}_{42}$ & -0.247 & -2.13 & $0.033^{* *}$ & -0.032 & -0.024 & -0.056 \\
\hline $\mathrm{X}_{43}$ & -0.227 & -2.04 & $0.041^{* *}$ & -0.029 & -0.022 & -0.050 \\
\hline $\mathrm{X}_{44}$ & 0.118 & 1.47 & $0.142^{\mathrm{NS}}$ & 0.008 & 0.006 & 0.014 \\
\hline $\mathrm{X}_{45}$ & 0.213 & 1.98 & $0.048^{* *}$ & 0.026 & 0.019 & 0.045 \\
\hline $\mathrm{X}_{46}$ & 0.254 & 2.16 & $0.031^{* *}$ & 0.036 & 0.027 & 0.063 \\
\hline $\mathrm{X}_{47}$ & -0.240 & -2.10 & $0.036^{* *}$ & -0.032 & -0.024 & -0.056 \\
\hline $\mathrm{X}_{48}$ & -0.165 & -1.74 & $0.082^{*}$ & -0.015 & -0.011 & -0.026 \\
\hline Const & 0.796 & 2.53 & $0.011^{* *}$ & --- & --- & --- \\
\hline \multicolumn{7}{|c|}{ Pseudo R2 $=0.84, \mathrm{LR}=802.07$} \\
\hline
\end{tabular}

NS: not significant- * significant at $90 \%$ interval level- ** significant at $95 \%$ interval level- $* * *$ significant at $99 \%$ interval level

Source: research finding 
Findings of table1 indicates that between 10 latent variables, Loan properties (G1), Company's banking account properties (G3), Banking guaranty's type (G8) and Bank monitoring (G10) have significant effect at 95\% interval level, Company properties (G2), Company's financial proportions (G4) and Economic situations (G9) have significant effect at 90\% interval level, and Loan type (G5), Company's type (G6) and Company's activity (G7) have no significant effect on bank loans default rate. After assessing the factors which affect the loan default rate with Delphi technique, and evaluating the effect of latent variables on loans default rate with SEM model, the Tobit econometric model was applied for investigating the elasticity of loan default rate to all assessed factors. According to the table2, in group of loan properties latent variable $\left(\mathrm{G}_{1}\right)$, loan volume except profit and penalty $\left(\mathrm{X}_{1}\right)$ has strong significant direct effect (at $99 \%$ interval level) on bank loan default rate. Also, total elasticity of this variable indicates that ceteris paribus with probability of 1 unit increase in $X_{1}$, default rate will increase 0.134 units which 0.077 units is belonged to partly recovered and 0.057 units is belonged to completely defaulted loans. Loan penalty $\left(X_{2}\right)$ has medium significant direct effect (at $95 \%$ interval level) on bank loan default rate. Also, total elasticity of this variable indicates that ceteris paribus with probability of 1 unit increase in $\mathrm{X}_{2}$, default rate will increase 0.060 units which 0.034 units is belonged to partly recovered and 0.025 units is belonged to completely defaulted loans. Loan profit rate $\left(\mathrm{X}_{3}\right)$ has medium significant direct effect (at $95 \%$ interval level) on bank loan default rate. Also, total elasticity of this variable indicates that ceteris paribus with probability of 1 unit increase in $\mathrm{X}_{3}$, default rate will increase 0.106 units which 0.061 units is belonged to partly recovered and 0.045 units is belonged to completely defaulted loans. Loan gap duration $\left(\mathrm{X}_{4}\right)$ has medium significant indirect effect (at 95\% interval level) on bank loan default rate. Also, total elasticity of this variable indicates that ceteris paribus with probability of 1 unit increase in $\mathrm{X}_{4}$, default rate will decrease 0.063 units which 0.036 units is belonged to partly recovered and 0.027 units is belonged to completely defaulted loans. Finally, loan repayment duration $\left(X_{5}\right)$ has medium significant indirect effect (at $95 \%$ interval level) on bank loan default rate. Also, total elasticity of this variable indicates that ceteris paribus with probability of 1 unit increase in $\mathrm{X}_{5}$, default rate will decrease 0.087 units which 0.050 units is belonged to partly recovered and 0.037 units is belonged to completely defaulted loans. In group of company's properties $\left(\mathrm{G}_{2}\right)$, company's background $\left(\mathrm{X}_{6}\right)$ has medium significant indirect effect (at 95\% interval level) on bank loan default rate. Also, total elasticity of this variable indicates that ceteris paribus with probability of 1 unit increase in $\mathrm{X}_{6}$, default rate will decrease 0.045 units which 0.026 units is belonged to partly recovered and 0.019 units is belonged to completely defaulted loans. Company's corporation with Bank Melli Iran $\left(\mathrm{X}_{7}\right)$ has weak significant indirect effect (at $90 \%$ interval level) on bank loan default rate. Also, total elasticity of this variable indicates that ceteris paribus with probability of 1 unit increase in $\mathrm{X}_{7}$, default rate will decrease 0.027 units which 0.015 units is belonged to partly recovered and 0.011 units is belonged to completely defaulted loans. Company's manager age $\left(\mathrm{X}_{8}\right)$, Company's manager background $\left(\mathrm{X}_{9}\right)$ and Professional education of manager coordination with company's activity $\left(\mathrm{X}_{10}\right)$ have no significant effect on bank loan default rate. Company's manager and boards delayed debt before loan allocation $\left(\mathrm{X}_{11}\right)$ has weak significant direct effect (at $90 \%$ interval level) on bank loan default rate. Also, total elasticity of this variable indicates that ceteris paribus with probability of 1 unit increase in $X_{11}$, default rate will increase 0.020 units which 0.012 units is belonged to partly recovered and 0.09 units is belonged to completely defaulted loans. Finally, company's co-grouping $\left(\mathrm{X}_{12}\right)$, has no significant effect on bank loan default rate. In group of Company's banking account properties $\left(\mathrm{G}_{3}\right)$, company's current account creditor flow at the loan allocation last year $\left(\mathrm{X}_{13}\right)$ has weak significant indirect effect (at $90 \%$ interval level) on bank loan default rate. Also, total elasticity of this variable indicates that ceteris paribus with probability of 1 unit increase in $\mathrm{X}_{13}$, default rate will decrease 0.038 units which 0.022 units is belonged to partly recovered and 0.016 units is belonged to completely defaulted loans. Company's current account creditor flow at the loan allocation year $\left(\mathrm{X}_{14}\right)$ has weak significant indirect effect (at $90 \%$ interval level) on bank loan default rate. Also, total elasticity of this variable indicates that ceteris paribus with probability of 1 unit increase in $\mathrm{X}_{14}$, default rate will decrease 0.026 units which 0.015 units is belonged to partly recovered and 0.011 units is belonged to completely defaulted loans. Company's total amount of direct debt to banking system $\left(X_{15}\right)$ has medium significant direct effect (at $95 \%$ interval level) on bank loan default rate. Also, total elasticity of this variable indicates that ceteris paribus with probability of 1 unit increase in $\mathrm{X}_{15}$, default rate will increase 0.054 units which 0.031 units is belonged to partly recovered and 0.023 units is belonged to completely defaulted loans. Company's total amount of indirect debt to banking system $\left(\mathrm{X}_{16}\right)$ has weak significant direct effect (at $90 \%$ interval level) on bank loan default rate. Also, total elasticity of this variable indicates that ceteris paribus with probability of 1 unit increase in $\mathrm{X}_{16}$, default rate will increase 0.031 units which 0.018 units is belonged to partly recovered and 0.013 units is belonged to completely defaulted loans. Finally, company's dishonoured cheque $\left(\mathrm{X}_{17}\right)$ has weak significant direct effect (at $90 \%$ interval level) on bank loan default rate. Also, total elasticity of this variable indicates that ceteris paribus with probability of 1 unit increase in $\mathrm{X}_{17}$, default rate will increase 0.036 units which 0.020 units is belonged to partly recovered and 0.015 
units is belonged to completely defaulted loans. In group of Company's financial proportion $\left(\mathrm{G}_{4}\right)$, cash flow/total debt proportion $\left(\mathrm{X}_{18}\right)$ has weak significant indirect effect (at $90 \%$ interval level) on bank loan default rate. Also, total elasticity of this variable indicates that ceteris paribus with probability of 1 unit increase in $\mathrm{X}_{18}$, default rate will decrease 0.041 units which 0.024 units is belonged to partly recovered and 0.018 units is belonged to completely defaulted loans. Assets flow proportion $\left(X_{19}\right)$ has weak significant indirect effect (at $90 \%$ interval level) on bank loan default rate. Also, total elasticity of this variable indicates that ceteris paribus with probability of 1 unit increase in $X_{19}$, default rate will decrease 0.023 units which 0.013 units is belonged to partly recovered and 0.010 units is belonged to completely defaulted loans. Free cash flow proportion $\left(\mathrm{X}_{20}\right)$ has weak significant indirect effect (at 90\% interval level) on bank loan default rate. Also, total elasticity of this variable indicates that ceteris paribus with probability of 1 unit increase in $\mathrm{X}_{20}$, default rate will decrease 0.026 units which 0.015 units is belonged to partly recovered and 0.011 units is belonged to completely defaulted loans. Total debt proportion $\left(\mathrm{X}_{21}\right)$ and Cash proportion $\left(\mathrm{X}_{22}\right)$ has no significant effect on default rate. Cash current proportion $\left(\mathrm{X}_{23}\right)$ has weak significant indirect effect (at $90 \%$ interval level) on bank loan default rate. Also, total elasticity of this variable indicates that ceteris paribus with probability of 1 unit increase in $\mathrm{X}_{23}$, default rate will decreases 0.028 units which 0.016 units is belonged to partly recovered and 0.012 units is belonged to completely defaulted loans. Finally, debt proportion $\left(X_{24}\right)$ has weak significant direct effect (at $90 \%$ interval level) on bank loan default rate. Also, total elasticity of this variable indicates that ceteris paribus with probability of 1 unit increase in $\mathrm{X}_{24}$, default rate will increase 0.024 units which 0.014 units is belonged to partly recovered and 0.010 units is belonged to completely defaulted loans. In group of loan type $\left(\mathrm{G}_{5}\right)$, Installment sale to industry, mine and agriculture sectors $\left(\mathrm{X}_{25}\right)$, Installment sale to industry, mine, services and agriculture sectors $\left(\mathrm{X}_{26}\right)$, Equity participation (real estate sector) $\left(\mathrm{X}_{27}\right)$, Equity participation (industry, mine and agriculture sectors) $\left(\mathrm{X}_{28}\right)$, Equity participation (trade and services sectors) $\left(\mathrm{X}_{29}\right)$ and Mudaraba (domestic trade and export sectors) $\left(\mathrm{X}_{30}\right)$ variables have no significant effect on default rate. In group of company's type $\left(\mathrm{G}_{6}\right)$, company's type: private joint stock $\left(\mathrm{X}_{31}\right)$, Company's type: public joint stock $\left(\mathrm{X}_{32}\right)$, Company's type: corporative $\left(\mathrm{X}_{33}\right)$ and Company's type: other $\left(\mathrm{X}_{34}\right)$ variables have no significant effect on default rate. In group of company's activity $\left(\mathrm{G}_{7}\right)$, company's activity: industry and mine sector $\left(\mathrm{X}_{35}\right)$, Company's activity: agriculture sector $\left(\mathrm{X}_{36}\right)$, Company's activity: real estate sector $\left(\mathrm{X}_{37}\right)$, Company's activity: services sector $\left(\mathrm{X}_{38}\right)$ and Company's activity: trade sector $\left(\mathrm{X}_{39}\right)$ variables have no significant effect on default rate. In group of banking guaranty's type $\left(\mathrm{G}_{8}\right)$, Bank guarantee: immovable property $\left(\mathrm{X}_{40}\right)$ has weak significant indirect effect (at $90 \%$ interval level) on bank loan default rate. Also, total elasticity of this variable indicates that ceteris paribus with probability of 1 unit increase in $\mathrm{X}_{40}$, default rate will decrease 0.027 units which 0.015 units is belonged to partly recovered and 0.011 units is belonged to completely defaulted loans. Bank guarantee: bank deposit or bonds $\left(\mathrm{X}_{41}\right)$ has weak significant indirect effect (at 90\% interval level) on bank loan default rate. Also, total elasticity of this variable indicates that ceteris paribus with probability of 1 unit increase in $\mathrm{X}_{41}$, default rate will decrease 0.037 units which 0.021 units is belonged to partly recovered and 0.016 units is belonged to completely defaulted loans. Bank guarantee: promissory note or cheque $\left(\mathrm{X}_{42}\right)$ has medium significant indirect effect (at $95 \%$ interval level) on bank loan default rate. Also, total elasticity of this variable indicates that ceteris paribus with probability of 1 unit increase in $\mathrm{X}_{42}$, default rate will decrease 0.056 units which 0.032 units is belonged to partly recovered and 0.024 units is belonged to completely defaulted loans. Finally, bank guarantee: other $\left(\mathrm{X}_{43}\right)$ has medium significant indirect effect (at 95\% interval level) on bank loan default rate. Also, total elasticity of this variable indicates that ceteris paribus with probability of 1 unit increase in $\mathrm{X}_{43}$, default rate will decrease 0.050 units which 0.029 units is belonged to partly recovered and 0.022 units is belonged to completely defaulted loans. In group of Economic situations $\left(\mathrm{G}_{9}\right)$, exchange rate $\left(\mathrm{X}_{44}\right)$ has no significant effect on default rage. Inflation rate $\left(\mathrm{X}_{45}\right)$ has medium significant direct effect (at $95 \%$ interval level) on bank loan default rate. Also, total elasticity of this variable indicates that ceteris paribus with probability of 1 unit increase in $\mathrm{X}_{45}$, default rate will increase 0.045 units which 0.026 units is belonged to partly recovered and 0.019 units is belonged to completely defaulted loans. Finally, economic sanction $\left(X_{46}\right)$ has medium significant direct effect (at $95 \%$ interval level) on bank loan default rate. Also, total elasticity of this variable indicates that ceteris paribus with probability of 1 unit increase in $\mathrm{X}_{46}$, default rate will increase 0.063 units which 0.036 units is belonged to partly recovered and 0.027 units is belonged to completely defaulted loans. In group of bank monitoring $\left(\mathrm{G}_{10}\right)$, bank control on loans $\left(\mathrm{X}_{47}\right)$ has medium significant indirect effect (at $95 \%$ interval level) on bank loan default rate. Also, total elasticity of this variable indicates that ceteris paribus with probability of 1 unit increase in $\mathrm{X}_{47}$, default rate will decrease 0.056 units which 0.032 units is belonged to partly recovered and 0.024 units is belonged to completely defaulted loans. Finally, company's financial reports auditing by official auditors association $\left(\mathrm{X}_{48}\right)$ has weak significant indirect effect (at $90 \%$ interval level) on bank loan default rate. Also, total elasticity of this variable indicates that ceteris paribus with probability of 1 unit increase in $\mathrm{X}_{48}$, default rate will decrease 0.026 units 
which 0.015 units is belonged to partly recovered and 0.011 units is belonged to completely defaulted loans.

\section{Summary and Conclusion}

There is a level of agreement among researchers on the crucial role of SMEs in economic development. According to missing evidence of the default model of loans to SMEs and lack of economic literature on the performance of SME loans, including their default rates in a developing economy, this paper modeled the effective factors on bank loans default rate using Delphi, SEM and Tobit techniques in Iran based on the case study of branches of Melli Bank in Khorasan Razavi province. For this purpose a set of data about loans made to 300 SMEs between years 2004 to 2015 and Delphi, SEM and Tobit models were applied. Results of Delphi technique indicated that 48 factors affect the DR. The structural equation model (SEM) estimations showed that between 10 latent variables which describe the DR, the "loans properties" latent variable have the most effect. Also, findings of Tobit econometric model stated that between 48 variables which affect the DR, "loan volume", "loan profit rate" and "loan repayment duration" variables have the most effect. These and other factors emphasize the need for SMEs credit scoring in developing countries.

\section{References}

Adejumo, D. G., \& Olaoye, J. A. (2012). Roles and Problems of Small-scale Business Development programmes in Nigeria. $I J M B S, 2(1)$.

Anderson, D. (1982). Small Industry in Developing Countries:A Discussion of Issues. World Development, 10(11), 913-948.

Apiri, T. R. (2013). Loan performance and default rate of financing SMEs by microfinance bank: a case study of accion microfinance bank PLC, Research report presented in partial fulfillment of the requirements for the degree of Master of Development Finance at the University of Stellenbosch.

Asarnow, E., \& Edwards, D. (1995). Measuring Loss on Defaulted Bank Loans: A 24-Year Study. The Journal of Commercial Lending, 77, 11-23.

Calomiris, C. W., \& Beim, D. O. (2001). Emerging Financial Markets, New York: McGraw-Hill/Irwin Publication.

Fidrmuc, J., Hainz, C., \& Malesich, A. (2006). Default Rates in the Loan Market for SMEs: Evidence from Slovakia. William Davidson Institute Working Paper, 854.

Fry, M. (1995). Money Interest and Banking in Economic Development (2nd Ed.).

Khieu, H. D., Donald, J. M., \& Ha-Chin, Y. (2011). The Determinants of Bank Loan Recovery Rates. Journal of Banking and Finance, forthcoming.

Kilby, P. (1971). Entrepreneurship and Economic Development New-York.

La Porta, R., Lopez-deSilanes F., \& Zamarripa, G. (2003). Related Lending. The Quarterly Journal of Economics, February, 231-268.

MacCallum, R. C., \& Austin, J. T. (2000). Applications of structural equation modeling in psychological research. Annual Review of Psychology, 51, 201-226.

Mora, N. (2012). What Determines Creditor Recovery Rates? Economic Review, 2, 79-109.

Oludayo, K. O. (2015). Determinants of Loan Default and Repayment Rates by Cassava Farmers in South-South Nigeria: A Case Study of Bank of Agriculture and First Bank of Nigeria. International Journal of Contemporary Applied Sciences, 2(9), 71-79.

Rowe, G., \& Wright, G. (1999). The Delphi technique as a forecasting tool: Issues and analysis. International Journal of Forecasting, 15(4), 353 - 375.

Saunders, A., \& Allen, L. (2002). Credit risk measurement, Second Edition. New York, John Wiley \& Sons.

Shah, W. H. (2014). SME Loan Defaults in Bangladesh, ARTNeT Policy Brief No. 41.

Skulmoski, G., \& Hartman, F. (2002). The Delphi method: Researching what does not exist (yet). Proceedings of the International Research Network on Organization by Projects, IRNOP V Conference, Renesse, The Netherlands.

Sutcliffe, R. B. (1971). Industry and under development, London, Addison-Wesley.

Sylvester, I., Okpara, G. C., \& Chukwudi, O. J. (2013). Determinants of Loan Size and Repayment Performance of Small Oil Producers in Nigeria: The Case Study of Abia State. International Journal of Business 
Management and Administration, 2(3), 43-54.

Wongnaa, C. A., \& Awonyu-Vitor, D. (2013). Factors Affecting Loan Repayment Performance among Yam

Farmers in the Sene District, Ghana. Agris Online Papers in Economics, V(2).

Wooldridge, J. (2002). Econometric Analysis of Cross Section and Panel Data. Cambridge: MIT Press.

Yong, S. J. (2011). The Study on Bank Strategy on Corporate and Home Loan Sales Evidence from Korean Banks' Loan Portfolio, Working paper, Sangmyung University.

\section{Copyrights}

Copyright for this article is retained by the author(s), with first publication rights granted to the journal.

This is an open-access article distributed under the terms and conditions of the Creative Commons Attribution license (http://creativecommons.org/licenses/by/4.0/). 